„Kwartalnik Filmowy” nr 115 (2021)

ISSN: 0452-9502 (Print) ISSN: 2719-2725 (Online)

https://doi.org/10.36744/kf.858

(c) Creative Commons BY-NC-ND 4.0

Malgorzata Radkiewicz

Uniwersytet Jagielloński

https://orcid.org/oooo-0001-6387-0810

\title{
Okiem awangardzistki. Kwestia formy w refleksji i realizacjach filmowych Germaine Dulac
}

\author{
Słowa kluczowe: \\ forma filmowa; \\ teoria filmu; \\ awangarda; \\ Germaine Dulac
}

\begin{abstract}
Abstrakt
Autorka omawia refleksje zamieszczone w publikacjach Germaine Dulac z lat 1919-1937, w których znajdują się odniesienia do jej przemyśleń oraz realizacji filmowych. Tematyka poruszana przez Dulac wpisuje się w dyskusję na temat kina jako sztuki, specyfiki nurtów awangardowych oraz wypracowywanej przez nie estetyki. Jako aktywna realizatorka, wykładowczyni i autorka tekstów śledziła na bieżąco dyskusje wokół filmu abstrakcyjnego, roli koloru, dźwięku, a także formowanie się profesji filmowych, które wymagały zdefiniowania. Interesowały ją ponadto zagadnienia związane $\mathrm{z}$ edukacją filmową i kształtowaniem się uniwersalnych kompetencji odbiorczych oraz rozwój rynku filmowego z nowoczesnymi kinami i międzynarodowym systemem dystrybucji.
\end{abstract}


W historii kina europejskiego Germaine Dulac pojawia się wśród twórców francuskiej awangardy, a jej filmy są przywoływane jako przykład eksperymentowania $\mathrm{z}$ formami impresjonistycznymi i surrealistycznymi ${ }^{1}$. Tymczasem $\mathrm{w}$ dziejach wczesnej myśli filmowej nazwisko Dulac (podobnie zresztą jak Marie Epstein) prawie nie funkcjonuje, chociaż z zaangażowaniem brała ona udział w dyskusjach na temat kształtu kina jako sztuki o niepowtarzalnych środkach wyrazu. Przypomnienie jej refleksji jest szczególnie ważne, jeśli chcemy analizować wkład kobiet w rozwój sztuki filmowej oraz poświęcone jej rozważania teoretyczne.

Dla Dulac jako przedstawicielki modernizującego się świata refleksja teoretyczna była równie ważna jak działania praktyczne. Jej kolejnym realizacjom kinowym towarzyszyły publikacje na łamach prasy specjalistycznej oraz feministycznej, w których omawiała kwestie dotyczące teorii oraz własne działania twórcze. Rozproszone teksty Dulac z lat 1919-1937 zostały wydane w zbiorze zredagowanym przez znawcę i edytora pism francuskiej awangardy Prospera Hillaireta $^{2}$. We wstępie do tomu podkreślał on przede wszystkim oryginalność i pionierskość działań reżyserki, widoczną zarówno w jej filmach, jak i poglądach na temat kina, omawianych $w$ prasie, na wykładach lub podczas prelekcji towarzyszących pokazom.

Z perspektywy rozwoju formy filmowej najciekawsze są teksty Dulac napisane przed 1929 r., kiedy świadomie podjęła decyzję o zaprzestaniu reżyserowania, nie odnajdując się $\mathrm{w}$ poetyce ani w polityce komercyjnego kina dźwiękowego. W powstałych do tego momentu pismach oraz wystąpieniach wyraźnie widać wychwycone przez twórczynię tendencje w rozwoju myśli filmowej i nurtów awangardowych, a także sposoby, w jakie ona sama oraz inni twórcy próbowali weryfikować własne przemyślenia na planie, podczas pracy z kamerą. Zdaniem Tami M. Williams ${ }^{3}$, znawczyni twórczości Dulac, jej publikacje stanowią rodzaj mapy zarówno jej indywidualnej kariery filmowej, jak i toczących się we Francji debat teoretycznych. Poruszane przez artystkę kwestie świadczą o wyczuleniu na transformacje zachodzące w modernizującym się świecie, na nowinki techniczne oraz ich wpływ na estetykę i warsztat filmowy. Dulac na bieżąco śledziła dyskusje wokół filmu abstrakcyjnego, roli koloru i dźwięku, a także formowanie się profesji filmowych, zwracając przy tym uwagę na często pomijany udział kobiet w rozwoju wczesnego kina. Interesowały ją ponadto zagadnienia związane z edukacją filmową i wypracowywaniem uniwersalnych kompetencji odbiorczych oraz rozwój rynku filmowego z nowoczesnymi kinami i międzynarodowym systemem dystrybucji.

\section{Istota kina jako sztuki}

Najważniejszą kwestią we wczesnych zapiskach Dulac była istota kina jako sztuki, która czerpie z istniejącej tradycji, lecz ma swoją specyfikę określającą typy twórczości i odbioru. Jak przystało na awangardową artystkę i aktywistkę, reżyserka uważała się za współuczestniczkę rewolucyjnego procesu przemian, w wyniku którego mogły wyłonić się nowatorskie, oryginalne sposoby myślenia oraz środki ekspresji. Dlatego Dulac wprowadzała w swoich rozważaniach perspektywę zarówno historyczną jak i współczesna, co pozwalało jej rozróżnić dwa podejścia do kina i formy filmowej. Pierwsze było związane z wynalazkiem Augusta i Lud- 
wika Lumière'ów, który spowodował, że skupiono się przede wszystkim na możliwościach mechanicznej, dokładnej rejestracji życia w ruchu $u^{4}$ W efekcie kinematograf zaczął funkcjonować jako instrument naukowy, jako narzędzie do precyzyjnego zapisu świata widzialnego $0^{5}$. Drugie podejście wiązało się z postawą jaką przyjęli artyści - żonglerzy myśli ${ }^{6}$. Odkryli oni, że kino ma duszę, że jest w nim potencjał intelektualny ${ }^{7}$, pozwalający mu nie tylko wyjść poza ramy nauki, ale też z impetem wkroczyć na teren sztuki i naruszyć jej wielowiekową tradycję. Dulac podkreślała znaczenie faktu, że mimo oporu ze strony tradycjonalistów pojawili się filmowcy, którzy jako artyści nie chcieli się wypowiadać w żadnej z dotychczasowych form, poszukiwali zaś dla siebie miejsca w sztuce ruchu ${ }^{8}$, czyli w kinie będącym dla nich jedyną w swoim rodzaju formą ekspresji.

W przeciwieństwie do Ricciotta Canuda i jego idei siódmej sztuki, czyli kina jako syntezy wcześniejszych sztuk, Dulac skłaniała się raczej ku tezie, że kino nie może być postrzegane jedynie jako odbicie innych sztuk, bowiem jest czymś znacznie ważniejszym, żeby być tylko refleksem ${ }^{9}$. Aby w pełni wykształcić własny charakter, powinno wręcz wyswobodzić się z więzów z innymi sztukami, zwłaszcza że posługuje się zupełnie odmienną techniką i koncentruje na ciągłości ruchu, a nie tylko na jego fazach, jak malarstwo czy fotografia. I choć można by uznać, że w pewnym stopniu bliższe jego specyfice pozostają dramat (z jego ewolucją zdarzeń i postaci), powieść (z zawartym w niej ruchem idei) czy muzyka (rozwijająca się w żywych, zmiennych harmoniach), to jednak - zdaniem Dulac - jest to podobieństwo pozorne, fatszywe i szkodliwe ${ }^{10}$. Szkodliwe dlatego, że od samego początku ograniczało myślenie o kinie jako nowym środku wyrazu - nowatorskim i mającym swój potencjał artystyczny. Brak dyskusji nad estetycznymi, a nie tylko handlowymi aspektami kina Dulac łączyła z faktem, że wraz z wynalezieniem kinematografu nie od razu pojawili się filmowcy, czyli artyści pragnący wypowiadać się w sztuce ruchu, poszukujący sposobów nowej ekspresji artystycznej. W efekcie narzędzie (instrument) było wcześniej niż ręka (myśl twórcza), forma wyprzedziła sztukę ${ }^{11}$. Właśnie dlatego istotą wczesnego kina i podstawą stosowanych w nim rozwiązań formalnych było poruszanie i przemieszczenie ${ }^{12}$, oznaczające mnożenie scen, scenografii i punktów widzenia oraz uatrakcyjnianie i ożywianie akcji dramatycznej. W dodatku dokonano wówczas klasyfikacji obrazów kinowych jako nowego rodzaju ekspresji literackiej, opartej na idei następstwa zdarzeń i sytuacji, oraz zaprzęgnięto [je] do "opowiadania historii"13.

Tymczasem - stwierdzała Dulac - kino zostało zupełnie niesłusznie wciśnięte w ramy istniejących sztuk i podporządkowane staremu myśleniu, podczas gdy ze względu na nowatorskość jego formy trzeba byłoby szukać w nim sposobu na poszerzanie ludzkiej wrażliwości i ludzkiego doświadczenia ${ }^{14}$. Z jednej strony należałoby więc docenić edukacyjny walor filmów dokumentalnych i naukowych, pokazujących to, czego ludzkie oko nie może zobaczyć lub widzi w ograniczonym zakresie - od życia przyrody po dalekie kraje i kontynenty. Rejestracja na taśmie sprawia, że kino jest okiem szeroko otwartym na życie, obserwującym w sposób z niczym wcześniej nieporównywalny ${ }^{15}$. Jednak z drugiej strony za specyficznymi naukowymi i materialnymi właściwościami kina jako nowej sztuki powinno iść stworzenie odrębnej teorii sztuki wizualizacji myśli ${ }^{16}$.

Dulac odwracała myślenie o powinowactwie kina i sztuk tradycyjnych, mówiąc o tym, że forma filmowa oparta na zasadach syntezy i harmonijnego ruchu 
charakteryzuje się koncentracją wrażeń i przyspieszeniem, jakiego nie mają inne rodzaje wypowiedzi artystycznych. W swoich poglądach była niezwykle radykalna; twierdziła, że literatura i teatr nie mogły wpływać na rozwój kina, wręcz przeciwnie - same uległy jego wpływowi. Pogląd ten odzwierciedla idealistyczną postawę awangardzistki, nastawionej na nowatorstwo i rozwój przez odrzucanie tego, co zastane. Dlatego nie odnosiła się do zjawisk takich jak Film d'art ani spektakularnych adaptacji, choćby scen biblijnych, bowiem uznawała, że nawet jeśli kino sięga po powieść czy utwór dramatyczny, to powstaje wówczas dzieło nowe, niejako obok pierwowzoru. Co więcej, kino jako sztuka dla oka wymaga sobie tylko właściwej myśli wizualnej, która pozwoliłaby dostrzec, że jest ono sztuka prawdy $i$ niuansu, z których wyłania się również to, co niematerialne ${ }^{17}$. Wedle Dulac kina nie ograniczają bowiem materialne narzędzia, jak glina czy płótno, ani słowa i ramy zdania. Podobnie jak muzyka, nie ma ono ściśle wyznaczonych granic, jeśli chodzi o przekazywanie emocji i wrażeń - to bowiem robi przez ruch obrazów. Kinowa idea wizualna byłaby więc artystyczna ewolucja, rozwojem nowej formy wrażliwości $i^{18}$. Jej realizację stanowiłby film integralny ${ }^{19}$ - wszyscy, jak pisze Dulac, chcieliby go stworzyć - będący rodzajem wizualnej symfonii zbudowanej z podporzadkowanych rytmowi obrazów, uporządkowanych jedynie dzięki woli i wrażliwości artysty ${ }^{20}$.

Tego rodzaju kino, tak jak muzyka, może wzbogacać uczucia i emocje, przy czym robi to za pomocą ruchu światta ${ }^{21}$, poruszającego duszę widza. Skoro istnieje symfonia - muzyka czysta - to dlaczego, pytała Dulac, kino nie miałoby mieć swojej symfonii? Argumentowała przy tym, że w kinie liczą się przede wszystkim związki między obrazami i - jak w każdej sztuce - najważniejsze są tu nie zdarzenia zewnętrzne, lecz ich wewnętrzna emanacja, ruch rzeczy i osób, postrzegany przez pryzmat $d u s z y^{22}$. Jednocześnie jako praktykująca reżyserka ubolewała nad tym, że choć każde dzieło sztuki jest dziełem personalnym, to jednak filmowcy nie mają prawa do osobistej, nieskrępowanej wypowiedzi. Muszą bowiem podporządkować swoją wrażliwość dziełom już znanym, akceptowanym przez publiczność, która - jak optymistycznie dodawała - zaczyna się różnicować. Dulac zwracała się więc do widzów, podkreślając, że błędem byłoby pozostawianie sztuki filmowej w krępujących ją więzach, bowiem film, jako sztuka przyszłości, jest większy i wspanialszy od głupich historyjek, jakimi się karmi i jakie każemy mu opowiadać23. Największe wyzwanie według niej to stworzyć kino $c^{2} y s t e^{24}$, podporządkowane walorom formalnym, a nie przyjemności narracyjnej.

\section{Idee i praktyki wizualne}

Dla Dulac, mimo jej zaangażowania w rozwijanie myśli filmowej, najważniejsze pozostawało przełożenie teorii na działania praktyczne. Jak na awangardzistkę przystało, dbała o to, by jej argumentacja w tekstach pisanych albo podczas prowadzenia wykładów odwoływała się do konkretnych realizacji i zabiegów reżyserskich. Pozwalało jej to zaprezentować warsztat - zarówno własny, jak i współczesnych jej twórców - oraz omówić najważniejsze zjawiska na obszarze X muzy. W tekście dla „Le Film” z 1919 r. ${ }^{25}$ Dulac wprost mówiła o tym, że w zasadzie w kwestii kina jako sztuki wszystko już zostało powiedziane, należy więc w ciszy zająć się pracą i czynić postępy, które będą bardziej korzystne dla rozwoju formy filmowej niż teorie. Jak zaznaczała: Myślenie zbyt dużo o przeszkodach na naszej 

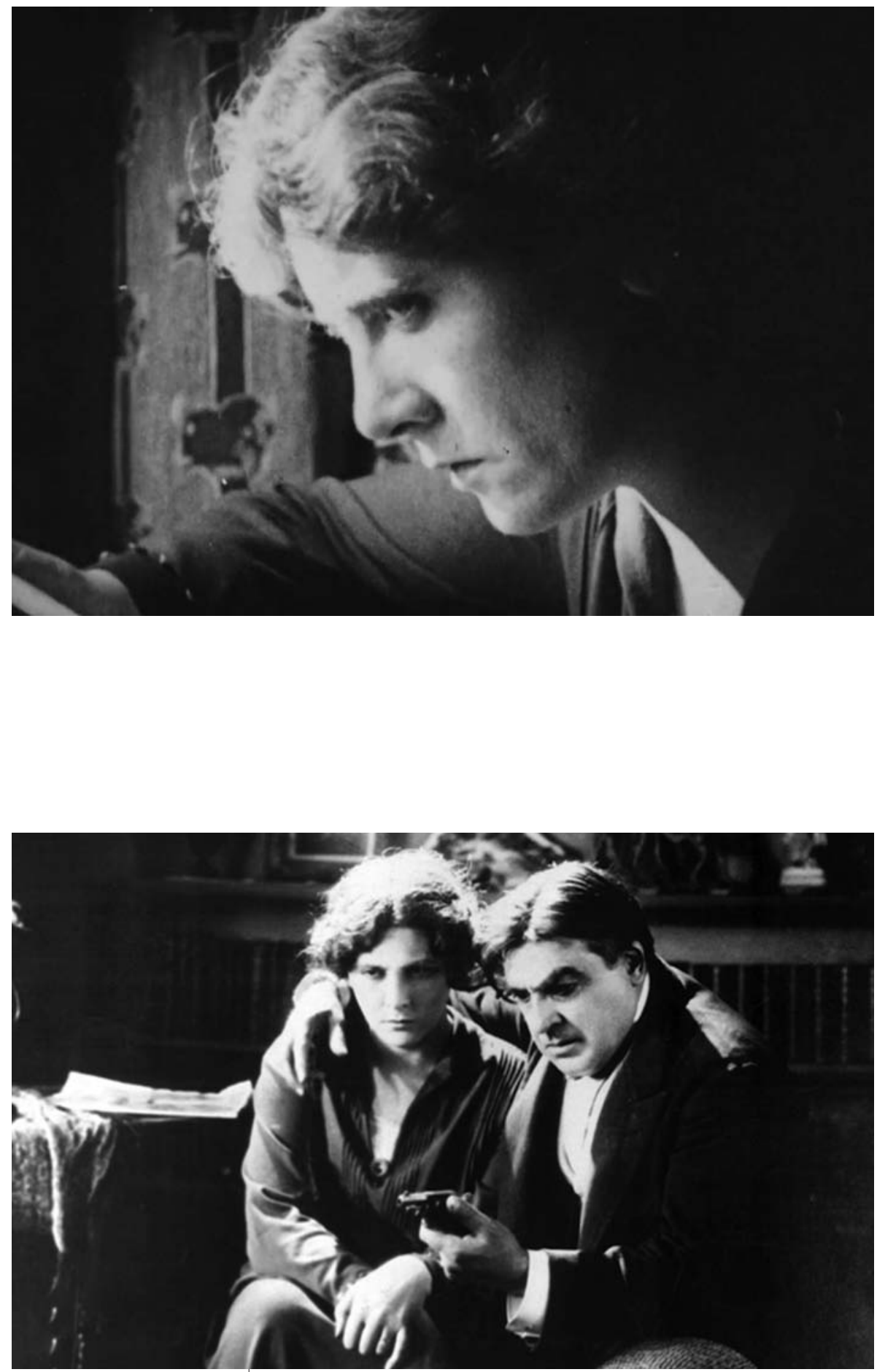

Uśmiechnięta pani Beudet, reż. Germaine Dulac (1923) 

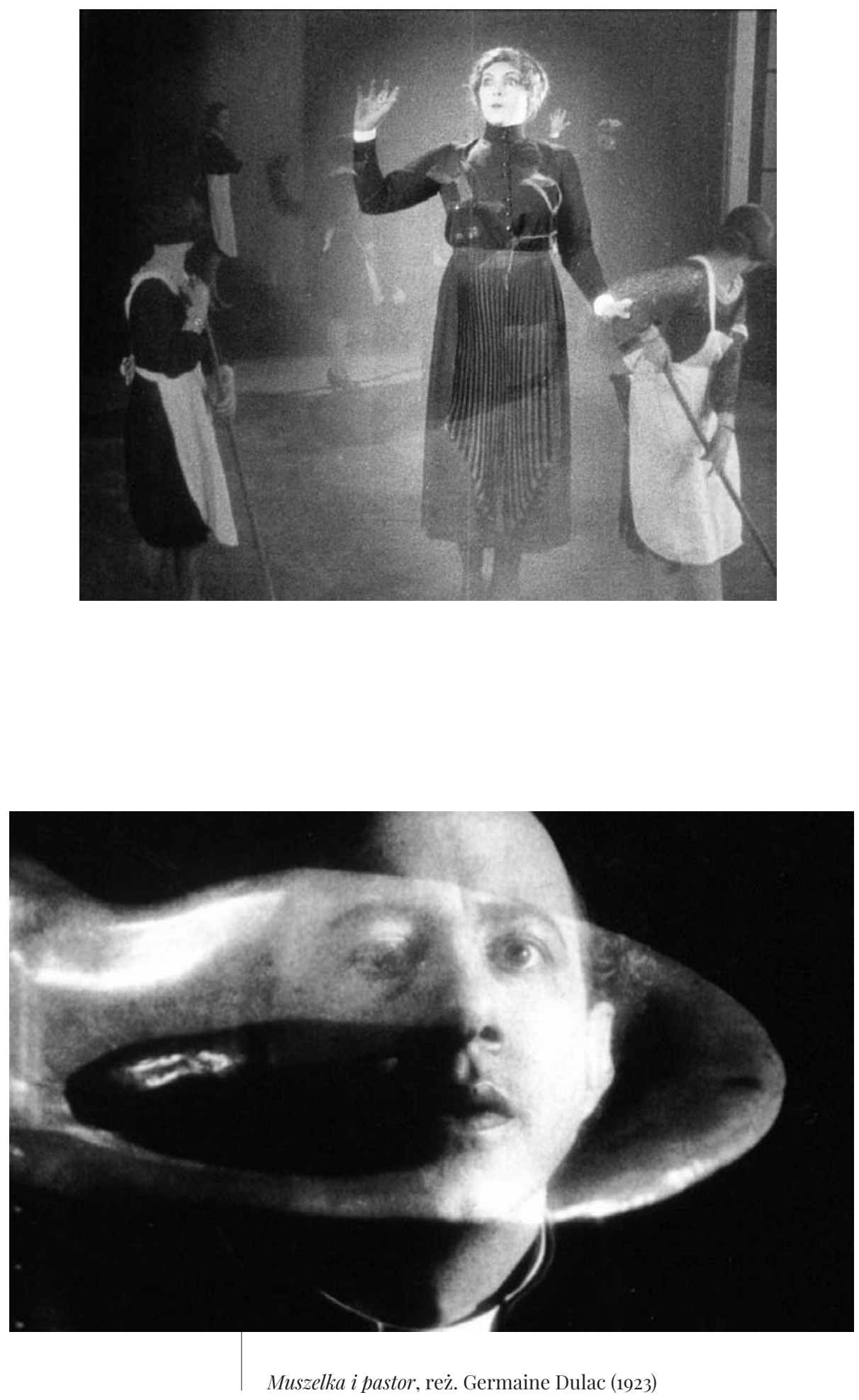
drodze nie jest najlepszym sposobem, by je pokonaćc ${ }^{26}$. Uważała, że ci spośród twórców, którzy naprawdę mają jakąś myśl wartą wyrażenia, zrobią to przez kino, bez względu na zewnętrzne przeszkody, kreując świetne dzieła. Odwołując się do własnego doświadczenia, dodawała, że problemem jest brak wiary w siebie, zwłaszcza iż wielu filmowców w poszukiwaniu perfekcjonizmu ciągle spogląda na wysiłki innych, szczególnie tych ze Stanów Zjednoczonych, próbując ich naśladować. Tymczasem, stwierdzała Dulac, nadszedł czas, by wyrazić nasza osobista wizje, zdefiniować nasza wrażliwość i określić własna ścieżkę ${ }^{27}$. Najważniejsze, by nie kopiować, lecz kreowaća ${ }^{2}$.

Jednym ze źródeł inspiracji, choć niekoniecznie materiałem do kopiowania, było dla Dulac kino amerykańskie. O swoich wrażeniach z wizyty w studiu filmowym Davida W. Griffitha pisała dla „Cinéa” w czerwcu 1921 r., przyznając, że oglądając je, ma się wrażenie równocześnie indywidualnej anonimowości, ale i sukcesu produkcji, a całość jawi się jako fabryka wspaniałej nowoczesnej wyobraźni ${ }^{29}$. W związku z tym stawiała pytanie o to, czy faktycznie obrazy filmowe, aby osiągnąć najwyższą perfekcję, muszą być oparte na pracy zespołowej osób, którym przydzielono konkretne obowiązki wynikające z sektora produkcji, czy też mogą one służyć przekazaniu wizji tylko jednego artysty, jak to się dzieje w rzeźbie, malarstwie, literaturze albo muzyce. Wytwórnia Griffitha nie mieściła się w industrialnym budynku fabryki, ale bardziej przypominała miejsce, w którym reżyser snuje swoje plany i wizje. Dulac przyznawała z pewnym zaskoczeniem, że spodziewała się atmosfery studia filmowego, a znalazła studio artysty, w którym dopracowuje się środki wyrazu związane z aktorstwem, sposobami inscenizacji i oświetleniem. Reżyserka spotkała w końcu Griffitha, o którym pisała, że spoglada na ciebie w poszukiwaniu nieodkrytych i tajemniczych właściwości wewnętrznych ${ }^{30}$.

$\mathrm{Z}$ ich rozmowy wynika, że zamiarem reżysera, a także jego osiągnięciem, było sprawienie, by kino odróżniało się od innych form sztuki, odsłaniało własne cele i swą wielkość oraz osobowość. To właśnie Griffithowi przypisywała Dulac siłę współczesnej im techniki filmowej, wykorzystującej zbliżenia do ukazania głębi uczuć postaci oraz zamglone obrazy rozmywające typowe przedstawienia i stosującej w komponowaniu kadrów opalizujące, wycieniowane kolory. Amerykański twórca zapytany o to, czy reżyser powinien być pojedynczym autorem filmu, odpowiadał, że od niego pochodzi pomysł, ale potem ulega on transformacjom i się od niego odcina. Dulac dodała do tego stwierdzenia komentarz: Griffith nie wspomniat, że z nudnej historii, ze sztuki teatralnej majacej sztywna strukturę stowna $i$ dramatyczna, wybiera pomyst i wzmacnia go, by wykreować nowe życie, bogate w realizm i symbole ${ }^{31}$. Podkreślała również fakt, że posiadł umiejętność kreowania i kontrolowania przebiegu akcji, między innymi dzięki odpowiedniej długości kadrów powiązanych z rytmem korespondującej z nimi muzyki.

Swoje obserwacje z amerykańskiego studia podsumowała stwierdzeniem, że każde dzieło kinowe, które ma wartość, musi być rezultatem jednostkowej woli decydującej o jego zmysłowości i sile. W przemyśle, jak twierdziła, podział zadań jest jak najbardziej na miejscu, ale nie w sztuce. Nic dziwnego - zauważała reżyserka - że Griffith ucieka od ustalonych schematów, udowadniając, iż indywidualizm jest cechą wielkiego dzieła filmowego, podobnie jak wszystkich wielkich dzieł sztuki. Kwestia roli i funkcji twórców filmowych oraz ich wpływu na formę realizacji powróciła w tekście dla „L'Écho de Paris” z 15 kwietnia 1922 r., w którym 
Dulac próbowała zdefiniować pojęcie metteur en scène $e^{32}$ oznaczające reżysera-realizatora. Wyjaśniała, że w rzeczywistości pod tym terminem kryje się artysta, który na zadany temat komponuje i zestawia ze sobą obrazy - filmowy ekwiwalent świata. To on decyduje o formie filmu, bowiem nie jest zwykłym organizatorem ruchu, lecz patrzy, czuje, kreuje namacalna myśl, wizualizuje dzieło sztuki ${ }^{33}$. Postulowała też, by używać specyficznego dla kina słowa „scenariusz” (scenario), gdyż oddaje ono charakter materiału pisanego wobec wizji, która czyni go realnym. Popierała również stosowanie nazwy „scenarzysta” dla podkreślenia, że jest to osoba przygotowująca scenariusz, a nie film.

\section{O formie filmowej}

Dulac na bieżąco komentowała dyskusje toczące się wokół X muzy, zabierając głos na temat kwestii warsztatowych i estetycznych. W wywiadzie udzielonym Paulowi Desclaux dla „Mon Ciné” z 23 października 1923 r. pojawiło się pytanie dotyczące formy filmowej ${ }^{34}$, na które Dulac odpowiedziała przewrotnie, że kino byłoby wspaniałą formą sztuki, gdyby specjalnie wprowadzało tryb warunkowy. Uważała bowiem, że wysiłki twórców, by włączyć kino do sfery intelektualnej i artystycznej, nie zawsze przynoszą rezultaty, jako że publiczność widzi w obrazach ekranowych przede wszystkim rozrywkę, substytut teatrów. Tymczasem kino stało się samoistną formą sztuki, przynoszącą niewyobrażalną obfitość nowych możliwości twórczych. Jej zdaniem kino nie jest tylko forma ekspresji faktów czysto zewnętrznych, ale także wizualizacja subtelnych niuansów duszy, wewnętrznego życia ${ }^{35}$. Dlatego nie uważała filmów przygodowych czy melodramatów za formułę prawdziwego kina, a filmy amerykańskie postrzegała jako pozbawione refleksji. Równocześnie dodawała, że nie sądzi, by w którymś ze swoich filmów osiągnęła ideał. Za najbliższy mu uznawała Uśmiechnięta pania Beudet (La souriante Madame Beudet /1923/) oraz planowaną na przyszłość realizację Zaproszenia do podróży (L'invitation au voyage /1927/), którego koncepcję oparła na omawianych ideach.

Kiedy pracowała jako krytyczka teatralna dla „La Française”, traktowała teatr jako formę ekspresji najbliższą jej wrażliwości, a dzięki uprawianiu krytyki mogła poprzez analizę dokonań innych poznać technikę dramatu. Było to dla niej ważne, gdyż początkowo sama chciała pisać sztuki teatralne. Ostatecznie jednak zdecydowała się na twórczość filmowa choć - jak przyznawała - na początku nie była w stanie w pełni zrozumieć potencjału ekspresji filmowej. Dopiero gdy zaczęła zajmować się ideami, emocjami, ze światłem i kamera, zrozumiała, że kino to tak naprawdę sztuka o wewnętrznym życiu i uczuciach, (...) potrafiaca uchwycić ducha ludzi i rzeczy ${ }^{36}$. Kino okazało się dla niej szansa, by wyrazić myśli w nowy, oryginalny sposób, co - jak przyznawała - odkryła dopiero po zrobieniu swojego pierwszego filmu, Les soeurs ennemies (1915).

Na pytanie o przyszłość kina Dulac odpowiedziała, że będzie to sztuka uczuć. Z historia oparta nie na elementach dramatycznych, ale emocjonalnych. Bardziej sztuka introspektywna niż ekstraspektywna ${ }^{37}$. Do strony formalnej realizacji filmowych powróciła w wykładzie zatytułowanym The Expressive Processes of Cinematography z 17 czerwca 1924 r. (opublikowano go w „Cinémagazine” w lipcu 1924 r.), wygłoszonym w Musée Galliera przy okazji wystawy poświęconej kinu. Dulac omówiła właściwe mu najważniejsze środki techniczne, wyjaśniając na przykładach 
(w trakcie wykładu pokazywano fragmenty filmów), na czym polega ich zastosowanie i rola w budowaniu formy filmowej. Zajęła się między innymi kwestią zróżnicowanych ujęć i punków widzenia. Zaczęła od stwierdzenia, że kino jest sztuką niema, a pozbawiona dźwięku ekspresja jest formalnym prawem ${ }^{38}$. Jak zauważała, mimo wszechobecności słowa w życiu codziennym filmowcy pozbyli się nawyku jego używania, żyjąc w świecie wizji wypełnionych forma $i$ wrażeniami ${ }^{39}$. Głównym sposobem komunikacji i wyrażania myśli są zatem w kinie obrazy i gesty, zastępujące słowa i czyniące filmowców małomównymi ${ }^{40}$, za to wyczulonymi na obserwację i rejestrację wrażeń.

Gdy mówiła o ekspresji filmowej, odwoływała się przede wszystkim do środków związanych z pracą kamery i funkcjami różnych ujęć, planów czy kadrów (zaciemnianych, rozjaśnianych lub tracących ostrość), do zdjęć nakładanych albo zniekształconych. Podkreślała przy tym, że wszystkie te środki są dla niej znacznie prostsze w użyciu niż manipulowanie słowami i tekstem. Zaznaczając, że zamiast prowadzić wykład, wolałaby przedstawić praktyczne możliwości kamery, podkreślała znaczenie faktu, iż sztuka filmowa bazuje na formie wizualnej. Natomiast mówiąc o ruchomych obrazach, opartych na geście i ulotnych wrażeniach, wyjaśniała, że ich wymowność wywodzi się z niemej, pozbawionej dźwięku komunikacji. Według Dulac retoryka kina zasadza się właśnie na ruchomych obrazach, a kontrasty i wywoływane przez nie zaangażowanie stanowią nośnik dla emocji kłębiących się w ciszy. Odwołując się do konkretnych sekwencji, jakie jej samej udało się zrealizować, stwierdzała, że kiedy nie ma słów, wybór, długość i rytm ujęć oraz ich kontrastowe zestawianie stanowią podstawowe środki wyrazu oraz źródło emocji (jak choćby montaż ujęć przedstawiających otwartą i zamkniętą przestrzeń, miejsca prywatne i publiczne).

Dlatego, zdaniem Dulac, na kino należy patrzeć przez pryzmat nie innych sztuk, ale jego własnych możliwości i sił oddziaływania, związanych z bezdźwięczną kompozycją i głośna ciszą ${ }^{41}$ odzwierciedlającą ludzkie emocje. Kontrastowość kadrów napędza akcję i tworzy atmosferę oddającą wewnętrzne nastroje oraz stan ducha postaci. Najważniejsze w kompozycji - majacej niemal wartość matematyczną ${ }^{42}$ - jest zestawianie ze sobą ujęć (często na zasadzie przeciwieństwa), z których każde musi wywoływać określone wrażenie, podkreślać intencję twórczą. Reżyserka zwracała przy tym uwagę, że ustawienie kamery, wybór planu i punktu widzenia odgrywają kluczową rolę w sytuowaniu, podkreślaniu, izolowa$n i u^{43}$, które składają się na czysto kinowy proces budowania znaczeń. Ostatecznie o formie filmu decyduje zatem wiele przemyśleń, mnóstwo doświadczenia i umiejętności technicznych ${ }^{44}$.

W przekonaniu Dulac każde ujęcie to równocześnie miejsce, akcja, idea, a nie tylko część historii. Dla poparcia tych tez awangardzistka przywołała swój film Uśmiechnięta pani Beudet jako przykład ukazujący relację między coraz bardziej oddalającymi się od siebie małżonkami. Zmontowane ujęcia pustej ulicy symbolizującej smutek, rąk żony grającej na pianinie oraz dłoni męża liczącego pieniądze sugerują zupełnie inne osobowości, całkiem inne marzenia i życiowe ideały. Jak zauważała reżyserka, taka kompozycja rodzi przeczucie, że poezja i realizm wejda ze soba $w$ kolizję ${ }^{45}$, a także powoduje, że każda postać wyłania się z ujęć, które wyodrębniają jej odmienne gesty i wzmacniają kontrast między poszczególnymi osobami, przez co widoczny staje się rozkład więzi małżeńskich i ujawnia się panująca 
w domu małżonków oziębła atmosfera. Forma filmu stanowi więc rodzaj wspótgrania między ujęciami, z ich ruchem, a przede wszystkim $z$ ich psychologią ${ }^{46}$. Znaczenie ma również różnorodność ujęć - ich rola, intensywność i waga zmienia się zależnie od tego, czy są to zbliżenia, czy ujęcia z dystansu, a także od tego, czy łączą one, czy też oddzielają poszczególne elementy. Przy okazji Dulac nazwała zbliżenie ujęciem psychologicznym ${ }^{47}$, gdyż zawiera ono ideę postaci rzuconą na ekran, odzwierciedlając jej duszę, emocje, pragnienia. Zbliżenie jest także impresjonistycznym zapisem, przemijajacym oddziaływaniem rzeczy, które nas otaczają4. Przykładem może tu być zastosowane w Uśmiechniętej pani Beudet zbliżenie ucha kobiety mieszkającej w sąsiedztwie małżonków, mogące budować konotacje z plotkami oraz prowincjonalnym życiem i właściwymi mu konfliktami, sprzeczkami czy kłótniami ludzi o ograniczonych horyzontach. Dulac zaznaczała, że za użyciem zbliżenia powinna stać koncepcja reżyserska, bowiem jest to zbyt ważny filmowy środek wyrazu, by go stosować bez przekonania, iż jest absolutnie niezbędny.

Innymi środkami ekspresji, które Dulac uważała za istotne w budowaniu narracji wizualnej, są zdjęcia nakładane, rozmaite nieostrości i zniekształcenia obrazów. To właśnie zdjęcia nakładane pozwalają - zdaniem reżyserki - na podkreślenie subiektywizmu oglądu postaci i ukazanie jej życia wewnętrznego, drzemiących w niej pragnień i targających nia, często sprzecznych, emocji. Jako zwolenniczka oryginalnych form wizualnych uważała wręcz, że w ogóle sfera wyobraźni i fantazji jest niezwykle filmowa, właśnie dzięki możliwości nakładania zdjęć, co pozwala ujawniać, kim jesteśmy, kiedy wychodzimy poza siebie ${ }^{49}$.

W wykładach Dulac wielokrotnie powracał wątek sztuki filmowej jako niemej, pozbawionej słów, opartej na ruchu, który otwiera przestrzeń nowych form ekspresji dla nowoczesnych artystów. Jako reżyserka i myślicielka polemizowała z twierdzeniem, że ruch jest ważny tylko wtedy, gdy stwarza akcję, kiedy wywołuje określone efekty. Jej zdaniem ruch nigdy nie jest daremny ani niepotrzebny, bowiem zawsze stanowi wynik przemyślanego działania, a jego rozwój jest skoordynowany z wyrażaniem określonych stanów, tworzeniem portretów postaci, ukazywaniem problemu. Wprowadza się go przede wszystkim po to, by wyodrębnić emocje $e^{50}$, co czyni sztukę filmową - mającą swój rytm - bliską muzyce. Jednak ruchome obrazy mają swoją specyfikę, ponieważ ruch jest skoncentrowany na uczuciu. Kino odchodzi od emocji muzycznych i osiaga emocje dramatyczna ${ }^{51}$. Dulac podkreślała, że nie nawołuje do wykluczania z ekranu wzruszających historii, tak lubianych przez publiczność. Stwierdzała jednak, że kiedy twórca próbuje w swoim filmie uciec od konwencji opowieści teatralnych, sprzecznych z duchem kina, to stara się poruszyć widzów przez uczucia, emocje, przez ruch rzeczy postrzeganych dla nich samych, by nam pomóc, by nas zrozumiećc ${ }^{2}$. Sama usiłowała osiągnąć to w filmie Gosette (1923), w którym ruch, aby mógł oznaczać stan umysłu, został podwojony w serii zestawionych ze sobą przeciwstawnych ujęć, odnoszących się do różnych wątków. Pierwszy był związany z porwaniem młodej dziewczyny przez bandytów, drugi dotyczył stanu psychicznego ofiary porwania. Aby oddać ducha zniewolonej postaci, jej strach i niewinność, reżyserka zmontowała ujęcia zakręcających dróg, drzew oraz zwielokrotniony obraz głowy bohaterki. Starała się przy tym uczynić tematem akcji uczucie... nie historię, a jednak wrażenie... ${ }^{53}$ 


\section{Kino jako sztuka duchowych niuansów}

W wypowiedziach Dulac dominuje entuzjastyczny ton związany z nadziejami pokładanymi przez awangardzistów w pracy z kamerą jako nowatorskim, technicznym, a zarazem refleksyjnym sposobie ekspresji. W tekście dla „Cinéa-Ciné pour tous" ze stycznia 1925 r. stwierdzała ona, że na kino można spoglądać z wielu perspektyw, nie tylko przez pryzmat jego użycia, zwłaszcza że nie jest instrumentem danym nam do niewolniczego powielania naszych dawnych sposobów myślenia ${ }^{54}$. Nie da się go także ograniczyć do funkcji edukacyjnych, społecznych albo rozrywkowych, gdyż znacznie poza te sfery wykracza jako nowa, bezprecedensowa forma: Nie jest to ani substytut, ani forma popularyzacji, ale "nowa forma komunikacji"55. Kino ma swoją formę i surowy materiat, ma także swoją myśl ${ }^{56}$. Zdaniem reżyserki to od widowni zależy, czy pozwoli twórcom ją wydobyć, wspierając ich w poszukiwaniach i nie odrzucając innowacji, które moga sprawiać, że nasze filmy wygladaja dziwnie. To, co dziś może się wydawać błędem, jutro może być postrzegane jako prawda oczywista ${ }^{57}$. Dulac podkreślała, że kino jako sztuka ekspresji oznacza, iż jego techniki muszą być bardziej związane z psychologią niż z akcją tworzoną przez rozwój wydarzeń. Kino to sztuka duchowych niuansów; sa niuanse jednostki i niuanse ttumu. (...) Kino musi zostać wyzwolone z tyranii literatury i teatru dla dobra jego myśli $i^{58}$.

Germaine Dulac wyraźnie przeciwstawiała akcję filmową (rozumianą jako uczucie) scenariuszom opartym na sytuacjach dramatycznych, powstających przez nawiązania do literatury (takie potępiała). Według niej w kinie nie chodzi o to, by dokonać aranżacji sceny, przedstawić problem, a następnie go rozwiązać. Kino bowiem to symfonia, zatem powinno się odciąć od wszystkiego, co literackie - jak pisała dla „Le Soir” w kwietniu 1925 r.

Wielość możliwych stanowisk wobec formy filmowej odzwierciedla tytuł jej tekstu z 1925 r. o ataku na kino i jego obronie ${ }^{59}$. Przyznawała w nim: Bronię kina, tym samym dając twierdzącą odpowiedź na pytanie, czy kino jest atakowane. Źródłem tego ataku jest fakt, że kino nosi maskę zmieniająca jego oblicze $e^{60}$ - maskę, którą nakazuje mu nosić publiczność. Jej zdaniem kino w obecnym kształcie nie ma nic wspólnego z tym, które kiedyś uwiedzie bardziej oświecony tłum ${ }^{61}$. Uważała wręcz, że tradycję kina w większym stopniu buduje publiczność chodząca na filmy niż filmowcy, bowiem publiczność gzarantuje zwrot kosztów, na co bacza finansiści inwestujący $w k_{i n o}{ }^{62}$. Natomiast publiczność akceptuje przede wszystkim to, co ją bawi i co zawiera mierne idee. Progres w kinie osiąga się wtedy, gdy nie jest ono przywiązane do ustalonej tradycji. Jak zauważała Dulac, producent odrzuca te innowacje, które mogłyby umniejszyć komercyjny wymiar filmu. Potrzebna jest więc publiczność o otwartych umysłach, by kino zdobyło wolność swobodnego wyrażania własnych idei. Broniła zatem kina, kładąc odpowiedzialność na barkach widowni.

W wywiadzie na temat swojego filmu Âme d'Artiste (1924) zaznaczała, że należy przejść ponad murem ignorancji oddzielającym twórców od publiczności ${ }^{63}$. Jej zdaniem twórcy powinni zaznajomić widzów ze swoimi ideami oraz innowacjami, pamiętając, że ważne jest to, by zrozumieć, czego chce publiczność, ale i pozostać wiernym twórczym poszukiwaniom artystycznym - zwłaszcza gdy te poszukiwania mają na celu uwolnienie kina ze starych formuł, w których tkwi ono od momentu powstania. Takie działania Dulac nazywała "kinem postępu”. To kino musi 
być nowa forma ekspresji, forma myśli i emocji ${ }^{64}$. Zauważała przy tym, że filmowcy urodzeni już w epoce kinematografu zaczęli myśleć w kategoriach kinowych i nie martwiąc się o interwencje ze strony innych obszarów artystycznych, odrzucali stare formy, zwłaszcza te dotyczące dramaturgii i fabuły.

Teksty oraz wykłady Germaine Dulac pokazuja, że jej pracę na planie poprzedzała refleksja oraz gruntowne przemyślenia na temat istoty kina oraz możliwości jej awangardowej realizacji. Jako reżyserka i teoretyczka wykazywała się wrażliwością na zjawiska artystyczne związane z nurtami awangardowymi w teatrze i malarstwie, reagując na nie eksperymentami z zakresu formy i sposobów opowiadania. Jak sugeruje Hillairet ${ }^{65}$ we wstępie do wyboru pism Dulac, z pewnością odnalazłaby się ona w XXI w., funkcjonując jako pionierka nowych technik i form artystycznych oraz środków wyrazu. Jego zdaniem z pewnością formułowałaby teorie i realizowała obrazy - z wykorzystaniem technologii cyfrowych, wideo czy Internetu - poszerzające granice kina. W myśl tych słów na Germaine Dulac należy patrzeć jako na reprezentantkę awangardy skupioną na formach typowych dla kształtującej się sztuki filmowej, a zarazem dbającą o to, by była ona nieograniczona, kreatywna oraz innowacyjna, wolna od celów komercyjnych i konformistycznych. Można też w Dulac dostrzec prekursorkę kina i sztuki kobiet, w których ekspresja artystyczna i praktyka zawodowa łączą się z działalnością aktywistyczna, uprawianiem publicystyki i refleksji teoretycznej. Maya Deren jako przedstawicielka amerykańskiej awangardy filmowej, entuzjastka badań antropologicznych nad rytuałem i tańcem, również regularnie publikowała swoje przemyślenia. Stojąc za kamera, stosowała środki, które starannie analizowała i omawiała $w$ tekstach teoretycznych ${ }^{66}$. Podobne ukierunkowanie twórczości kobiet na teorię i praktykę artystyczną było widoczne w latach 70 . XX w. w trakcie drugiej fali feminizmu w Wielkiej Brytanii. W efekcie koncepcje tworzone przez Laurę Mulvey miały swoje bezpośrednie przełożenie na realizacje filmowe, a środki wyrazu wypracowane przez Sally Potter ${ }^{67}$ znalazły uzasadnienie w jej regularnie prowadzonych zapiskach i publikacjach.

${ }^{1}$ Analizę dokonań filmowych Germaine Dulac przeprowadziłam w tekście Indywidualistki we francuskiej awangardzie. Germaine Dulac, Claude Cahun i Marcel Moore, w: Historie filmu awangardowego. Od dadaizmu do postinternetu, red. Ł. Ronduda, G. Sitek, Fundacja Okonakino Muzeum Sztuki Nowoczesnej - Korporacja Ha!art, Warszawa - Kraków 2020.

${ }^{2}$ W 1990 r. Christian Lebrat stworzył serię Classiques de l'Avant-Garde, w której w 1994 r. ukazał się zbiór tekstów Germaine Dulac z lat 1919-1937, przetłumaczony następnie na angielski. Zob. G. Dulac, Writings on Cinema (1919-1937), red. P. Hillairet, tłum. S. Hammen, Paris Expérimental, Paris 2018 (edycja Kindle).

${ }^{3}$ T. M. Williams, Dulac's "Écrits" (Foreword), w: G. Dulac, Writings... dz. cyt., lok. 104.

${ }^{4} \mathrm{G}$. Dulac, Istota kina - wizualizacja myśli, tłum. I. Dembowski, w: Europejskie manifesty kina.
Od Matuszewskiego do Dogmy. Antologia, red. A. Gwóźdź, Wiedza Powszechna, Warszawa 2002, s. 171.

5 Tamże.

${ }^{6}$ Tamże.

7 Tamże.

8 Tamże.

9 Tamże, s. 172.

${ }^{10}$ Tamże, s. 173.

${ }^{11}$ Tamże.

12 Tamże.

${ }^{13}$ Tamże, s. 174.

14 Tamże, s. 175.

15 Tamże, s. 176.

16 Tamże.

17 Tamże, s. 177.

18 Tamże.

${ }^{19}$ Tamże.

${ }^{20}$ Tamże. 
${ }^{21}$ Tamże.

${ }^{22}$ Tamże, s. 178 .

${ }^{23}$ Tamże.

${ }^{24}$ Tamże.

${ }^{25}$ G. Dulac, Let Us Have Faith, w: tejże, Writings... dz. cyt., lok. 407.

${ }^{26}$ Tamże.

27 Tamże, lok. 417.

${ }^{28}$ Tamże.

${ }^{29}$ G. Dulac, At D. W. Griffith's, w: tejże, Writings... dz. cyt., lok. 422-423.

${ }^{30}$ Tamże, lok. 461.

${ }^{31}$ Tamże, lok. 476-477.

${ }^{32}$ G. Dulac, The Creation of a Cinematopographic Vocabulary, w: tejże, Writings... dz. cyt., lok. 514.

${ }^{33}$ Tamże, lok. 519-520.

${ }^{34}$ G. Dulac Interview with P. Desclaux, w: G. Dulac, Writings... dz. cyt., lok. 532.

35 Tamże, lok. 537.

${ }^{36}$ Tamże, lok. 557.

${ }^{37}$ Tamże, lok. 606.

${ }^{38}$ G. Dulac, The Expressive Processes of Cinematography, w: tejże, Writings... dz. cyt., lok. 613.

39 Tamże, lok. 624.

${ }^{40}$ Tamże.

${ }^{41}$ Tamże, lok. 682.

42 Tamże, lok. 707.

${ }^{43}$ Tamże, lok. 714.

${ }^{44}$ Tamże, lok. 732.

${ }^{45}$ Tamże, lok. 750.
${ }^{46}$ Tamże, lok. 754.

${ }^{47}$ Tamże, lok. 765.

${ }^{48}$ Tamże.

${ }^{49}$ Tamże, lok. 784.

${ }^{50}$ G. Dulac, Motion as Creator of Action, w: tejże, Writings... dz. cyt., lok. 1011.

${ }^{51}$ Tamże, lok. 1026.

52 Tamże, lok. 1038.

${ }^{53}$ Tamże, lok. 1071

${ }^{54}$ G. Dulac, Cinema, an Art of Spiritual Nuances, w: tejże, Writings... dz. cyt., lok. 1119.

55 Tamże, lok. 1125.

${ }^{56}$ Tamże, lok. 1148.

${ }^{57}$ Tamże.

${ }^{58}$ Tamże, lok. 1155.

${ }^{59}$ G. Dulac, Defence and Attack of Cinema, w: tejże, Writings... dz. cyt., lok. 1193.

${ }^{60}$ Tamże.

${ }^{61}$ Tamże.

${ }^{62}$ Tamże, lok. 1202

${ }^{63}$ G. Dulac, About "Âme d'Artiste", w: tejże, Writings... dz. cyt., lok. 1234

${ }^{64}$ Tamże, lok. 1239.

${ }^{65}$ P. Hillairet, Germaine Dulac: A Modern Filmmaker (Preface 2018), w: G. Dulac, Writings... dz. cyt., lok. 113-232.

${ }^{66}$ Zob. M. Deren, An Anagram of Ideas on Art, Form and Film, The Alicat Book Shop Press, New York 1946.

${ }^{67}$ Zob. S. Potter, Naked Cinema: Working with Actors, Faber and Faber, London 2014.
Malgorzata Radkiewicz
Prof. dr hab., filmoznawczyni; pracuje w Instytucie Sztuk Audiowizualnych Uniwersytetu Jagiellońskiego, gdzie kieruje Katedrą Historii Filmu Polskiego. Zajmuje się problematyką tożsamości kulturowej oraz twórczością kobiet w kinie, fotografii i sztuce współczesnej. Wyrazem jej zainteresowań są publikacje: W poszukiwaniu sposobu ekspresji. O filmach fane Campion i Sally Potter (2001), Wtadczynie spojrzenia. Teoria filmu a praktyka reżyserek i artystek (2010). Ponadto autorka książek: Derek Farman. Portret indywidualisty (2003), „Młode wilki” polskiego kina. Kategoria gender a debiuty lat 9o. (2006) oraz Oblicza kina queer (2014). W latach 2015-2018 koordynatorka projektu badawczego Narodowego Centrum Nauki: Pionierki z kamera. Kobiety w kinie i fotografii w Galicji 1896-1945, podsumowanego w licznych artykułach. Jako stypendystka Ministerstwa Kultury i Dzie- 
dzictwa Narodowego w 2015 r. prowadziła badania opublikowane w monografii Modernistki o kinie. Kobiety w polskiej krytyce i publicystyce filmowej 1918-1939 (2016). Członkini Polskiego Towarzystwa Kulturoznawczego oraz Polskiego Towarzystwa Badań nad Filmem i Mediami.

\section{Bibliografia}

Dulac, G. (2002). Istota kina - wizualizacja myśli (tłum. I. Dembowski). W: A. Gwóźdź (red.), Europejskie manifesty kina. Od Matuszereskiego do Dogmy. Antologia (ss. 170-178). Warszawa: Wiedza Powszechna.

Dulac, G. (2018). Writings on Cinema (1919-1939) (red. P. Hillairet, thum. S. Hammen, edycja Kindle). Paris: Paris Expérimental.

Hillairet, P. (2018). Germaine Dulac: A Modern Filmmaker (Preface 2018). W: G. Dulac, Writings on Cinema (1919-1937) (red. P. Hillairet, thum. S. Hammen, edycja Kindle, lok. 113-232). Paris: Paris Expérimental.

Williams, T. M. (2018). Dulac's "Écrits" (Foreword). W: G. Dulac, Writings on Cinema (1919-1937) (red. P. Hillairet, thum. S. Hammen, edycja Kindle, lok. 69-112). Paris: Paris Expérimental.

\footnotetext{
Keywords:

film form;

film theory; avant-garde;

Abstract

Małgorzata Radkiewicz

From an Avant-garde Perspective: Film Form in the Writings and Films of Germaine Dulac

Germaine Dulac

The text presents Germaine Dulac's ideas on cinema and film form, as discussed in her writings from 1919-1937. As a filmmaker and member of the avant-garde movement, Dulac addressed the issue of cinema as a new art form, and its original aesthetics. As an active director, lecturer, writer and editor of texts, she followed and commented on current discussions on abstract film, the role of color, sound, and new film professions that had to be defined. Moreover, Dulac was interested in film education, educating the audience, as well as in the development of film market and film industry.
} 